Journal of Contemporary Research in Social Sciences

ISSN : 2641-0249

Vol. 3, No. 2, pp. 28-39.

2021

Publisher: Learning Gate

DOI: 10.33094/26410249.2021.32.28.39

(C) 2021 by the authors; licensee Learning Gate

\title{
Implications of Bangladesh's Graduation from Least Developed Countries Status on Japanese Companies
}

\author{
USAMI Takashi \\ Assistant Director, Ministry of Economy, Trade and Industry, Government of Japan. \\ Email: usami-takashi@meti.go.jp \\ FUKUOKA Noriyoshi \\ Consulting Fellow, Research Institute of Economy, Trade and Industry (RIETI) and Director, Ministry of Economy, Trade and Industry, \\ Government of Japan. \\ Email: fukuoka-noriyoshi@meti.go.jp
}

Received: 8 April 2021; Revised: 10 May 2021; Accepted: 4 June 2021; Published: 21 June 2021

Abstract: In 2026, Bangladesh is expected to graduate from the Least Developed Countries status, which is reviewed by the Committee for Development Policy of the United Nations. While graduation has some advantages, such as improvement of the country's external image, it also has some disadvantages, such as the inability to use the special preferential measures that are granted to countries with that status by the international community. This study discusses the implications and impacts of such changes in business environment of Bangladesh on Japanese companies through a questionnaire-based survey. As a result, the study demonstrates that Japanese companies that operate in Bangladesh and that benefit from special preferential tariffs have already begun to gather information and are even considering transferring their production bases. In order to avoid losing such foreign direct investment, Bangladesh is looking into free trade agreements (FTAs), however, in addition, authors believe it is necessary for Bangladesh to develop a friendly business environment that is comparable to that of neighboring Southeast Asian countries, to strengthen its industrial competitiveness, and to improve the level of trade diversification. The Japanese government also needs to make further efforts to deepen bilateral economic relations. This study intends to contribute to the debate regarding the graduation status of Bangladesh, and to the policies and strategies of governments and businesses.

Keywords: Economic development, LDC, Bangladesh, Tariff, Trade, Supply Chains, Japan.

\section{Introduction}

Japan and Bangladesh have been in a good relationship ever since they established a diplomatic relationship in 1972. The relationship stepped up to be a "comprehensive partnership" in 2014, and has continued to deepen since then, with Japanese dignitaries visiting Bangladesh very frequently. Japan is now a Bangladesh's largest donor of bilateral aid, and major cooperation projects are underway such as the construction of the Matabari Ultra Supercritical Pressure Coal-fired Power Plant and the development of a special economic zones. Looking at the Japanese companies, we can also see that the number of companies entering the market is steadily increasing: from 83 companies in 2010 to 315 companies in 2020, a fourfold increase in the past 10 years. The reasons for this increase are such as the availability of abundant labor and the possibility of tapping into the huge domestic market of over 160 million population. It is also worth mentioning that industries of Japanese companies have started to diversify from textile to other sectors such as automobile and constructions. As such, Japan and Bangladesh have formed a deep bilateral relationship in both name and reality. 
Based on its economic indicators, Bangladesh falls under the category of Least Developed Countries (LDC) status, but its growth in recent years has been remarkable. In addition to maintaining a GDP growth rate of about $6 \%$ over the past decade, human development indicators such as life expectancy and poverty rates have improved significantly, and the International Finance Corporation (IFC) has described Bangladesh as "one of the developmental success stories" (International Finance Corporation (IFC), 2020). If authors were to introduce two opportunities that have attracted Japanese attention to Bangladesh, one would be the Goldman Sachs report in 2005, in which Bangladesh was selected as one of the Next 11 countries that could have a significant impact on global economy in 50 years. The second opportunity would be the Nobel Peace Prize granted to Grameen Bank and its founder, Muhammad Yunus, for their efforts to create economic and social development from the bottom and for pioneering the field of microcredit. The view towards Bangladesh has changed to see it as full of potentials and possibilities for the businesses.

Due to these economic and social improvements, Bangladesh is expected to graduate from LDCs within a few years. While graduation has some advantages, such as improvement of the country's external image, it also has some disadvantages, such as the inability to use the special preferential measures that are granted to countries with that status by the international community. However, the question is, what implications the graduation would have on Japanese companies. This study aims to respond to such a question, and to contribute to Japanese government's policies and Japanese companies' strategies to prepare for the business changes in Bangladesh.

The rest part of the article is arranged as follows. The second section deals with the review of the literature, with focus on industries of Bangladesh, history of global textile industries development, and the mechanisms of LDC status. The third section deals with methodology and the fourth section deals with findings and discussion. The final section concludes the article.

\section{Literature Review}

\subsection{Industries of Bangladesh}

To begin with, the Bangladesh's economy has steadily been increasing with strength. In the 1990s, the GDP per capita was between US $\$ 300$ and US $\$ 400$, but it has increased to US $\$ 1,855$ in 2019 . The increase has been particularly rapid in recent years, and has nearly tripled in the past decade (World Bank, 2021). In addition, the GDP growth over the past decade has averaged about $6 \%$, and the GDP growth for 2019 recorded $8.2 \%$, while annual inflation has been maintained at $5-6 \%$. The economy is also backed up by a huge working population and domestic demands, with estimated population of around 163 million and about $45 \%$ being under the age of 24 .

Looking at the industrial structure, we can see a huge dependence on textile industries. Figure 1 shows changes in the value of clothing exports and their share of total exports (Bangladesh Garment Manufacturers and Exporters Association (BGMEA), 2020). In 1983, clothing product exports accounted for only about $4 \%$ of total exports, while by 1990, they accounted for more than $50 \%$, and since 1997, they have occupied more than $70 \%$. In fact, tariff schedules chapter 62 (Articles of apparel and clothing accessories, not knitted or crocheted) and chapter 61 (Articles of apparel and clothing accessories, knitted or crocheted) alone account for about $83 \%$ of the total export volume. Thus, it is fair to say that the industrial growth of Bangladesh is largely due to the textile industry, and it is the major driving force of the economy. Besides, in terms of the country's share of the global apparel industry's exports, Bangladesh ranks second (7.3\%) after China (about 30\%) (Ministry of Economy Trade and Industry Government of Japan, 2020). The competitiveness of Bangladesh comes from such factors as its relatively low labor costs, large population, and high population density, which makes it easy to attract labors (General Economics Division Bangladesh Planning Commission Ministry of Planning Government of the People's Republic of Bangladesh, 2020; Kobayashi, 2013; Murayama \& Yamagata, 2014). According to Murayama and Yamagata (2014) labor cost in Dhaka is almost at the lowest level compared to other major cities in Asia. Although this issue of low level of wages is deeply connected to the economic and social situation in Bangladesh, and relates to discussions such as facilitation of 
business opportunities for women (Nagata, 2012) on one hand and poor working environment of the industry on the other hand, this article would not go into such detail.

In addition, Bangladesh's exports to Japan are similar to those to the rest of the world, with articles of apparel and clothing accessories accounting for about $80 \%$ of exports. Besides, Bangladesh's exports to Japan are in the fourth position (4\%) after EU (45\%), US (17\%), and UK (10\%) (Export Promotion Bureau Government of the People's Republic of Bangladesh, 2020) making Japan the most important country when Bangladesh looks at its neighboring Asian countries.

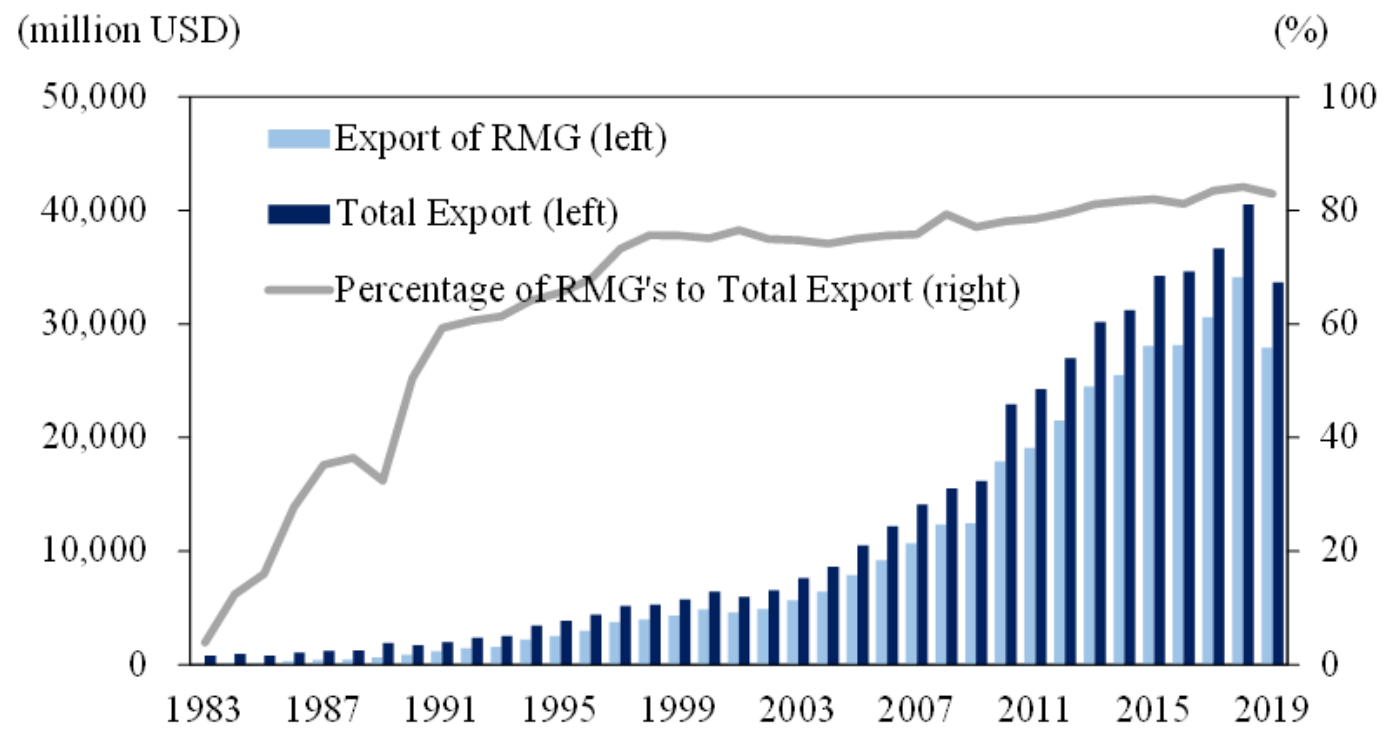

Figure-1.

Percentage and Volume of RMG and Total Export from Bangladesh.

Source: Bangladesh Garment Manufacturers and Exporters Association (BGMEA), 2020.

\subsection{History of Global Textile Industries Development}

The history of the development of the textile industry is tantamount to the history of global supply chains. This is due to the two characteristics of the textile industry - that textile industry is composed of simple and labor intensive processes and that it may be efficient to use the lower labor costs of developing countries - that makes itself easily affected by the external environmental changes such as trade measures. According to Gereffi (1999), the transfer of the global supply chains of the textile industry first occurred in the 1950 s and early 1960 s in the form of substitution from production in North America and Western Europe to production in Japan. Later, the production base moved from Japan to Hong Kong, Taiwan, and South Korea in the 1970s to the 1980s, then to China and Southeast Asian countries in the 1980s, and to South Asian countries including Bangladesh, Latin American countries, and Vietnam in the 1990s.

Fukasawa (2014) describes in detail the reasons for this shift in the global supply chains. In the 1950 s, when the production base of the textile industry shifted to Japan, where the labor was cheaper, the United States urged Japan to implement Voluntary Export Restraint (VER) fearing that their domestic textile industry would be negatively affected. In addition, the General Agreement on Tariffs and Trade (GATT) put into effect the Short-Term Agreement (STA) in 1961 and the Long-Term Agreement (LTA) in 1962, restricting the flow of cotton products from Asia. Following these developed countries' protective trade measures, the comparative advantage of establishing production bases in Japan became to fade away, and instead Hong-Kong, Taiwan and Korea emerged. In 1973, the MultiFiber Agreement (MFA) was signed and chemical products were added to the import restrictions, and in 1985, quota mechanisms were established by the United States and Canada. Under the restrictions, 
countries that exported more than the quota limit were subject to penalties for exporting the following year, and exporting countries were required to control their volume of exports so as not to exceed the quota limit (Murayama \& Yamagata, 2014). On the other hand, the quota mechanism was applied only to countries with large export volumes. Bangladesh, which at the time had only a small export volume, seized the opportunity of this global supply chain reconfiguration and successfully attracted textile companies.

In addition to MFA and low-cost wages, there are three other factors that have supported the development of textile industry in Bangladesh. First one is a bonded warehouse and second one is a back to back latter of credit (General Economics Division Bangladesh Planning Commission Ministry of Planning Government of the People's Republic of Bangladesh, 2020; Rahman, 2011). The former provides tax exemption by using warehouses designated by the Bangladesh government. The latter allows exchanging imported cloth and apparel made from it by simultaneously issuing an import letter of credit to the foreign company that placed the order and an export letter of credit to the Bangladeshi company that received the order. It has made it possible for Bangladeshi companies to obtain imported cloth without having to prepare foreign currency (Murayama \& Yamagata, 2014). The third factor is the special preferential tariff, which is one of the special preferential measures for LDCs (Komori, 2017; Rahman, 2011; Shintaku, Tomino, \& Itohisa, 2013). The status of being an LDC, which allows textile products to be exported duty-free, has greatly contributed to the development of the textile industry in Bangladesh, which will be detailed later in the article.

Japanese textile companies began to move to Bangladesh after the financial crisis, and Nagata (2012) analyzed the main reasons as follows. The pull factors on the Bangladesh side are strong macroeconomic conditions, expansion of the industrial sector, and abundant and quality labor force, while the push factors include rapid changes in the labor environment in China, namely rising wages, labor shortage, and frequent labor disputes. Ever since Fast Retailing Co., Ltd. opened a representative office in 2008, companies that deal with sewing, inspection, machinery, and other related procedures have entered the country one after another (Komori, 2017) attracting so much attention that the term "Bangla Pilgrimage" was even coined.

As mentioned above, Bangladesh has jumped to the center of the global supply chains, taking into account a variety of external and internal factors. In the history of this reconfiguration of supply chains, it needs to be considered what the Bangladesh's graduation from LDC status would cause in the near future, and whether or not Bangladesh would be able to secure the important position. This study would examine these questions in the context of Japanese companies.

\subsection{Mechanisms of LDC Status}

Details of LDC status are explained in the "Handbook on the Least Developed Country Category: Inclusion, Graduation and Special Support Measures" (United Nations, 2018). The LDC category was established by the United Nations General Assembly in 1971 based on the common understanding of the international community that special measures were necessary for the least developed countries among the developing countries. Inclusion and graduation from the LDC list are decided by the United Nations General Assembly based on the recommendation of the Committee for Development Policy (CDP). The list is reviewed every three years, with the most recent review meeting held in 2021.

The main feature of the inclusion and graduation process are that it uses three indicators and that countries need to meet at least two indicators at two consecutive review meetings in order to graduate. The country graduates from the LDC list three years after the second review, which is called the preparation period. The three indicators are described below:

(1) GNI per capita.

(2) HAI (Human Asset Index): An index of the degree of human resource development, which is based on under-five mortality rate; prevalence of stunting; maternal mortality ratio; gross secondary school enrolment ratio; adult literacy rate; and gender parity index for gross secondary school enrolment.

\begin{tabular}{l}
\hline Journal of Contemporary Research in Social Sciences \\
ISSN : 264.1-0249 \\
Vol. 3, No. 2, pp. $28-39,2021$ \\
DOI: $10.33094 / 26410249.2021 .32 .28 .39$ \\
C) 2021 by the authors; licensee Learning Gate
\end{tabular}


(3) EVI (Economic Vulnerability Index): An index of economic vulnerability to external shocks, which is based on share of agriculture, forestry, fisheries in GDP; remoteness and landlockedness; merchandise export concentration; instability of exports of goods and services; share of population in low elevated coastal zones; share of population living in drylands; instability of agricultural production; and victims of disasters.

As mentioned above, special preferential measures have been granted to LDCs. This can be categorized into three main aspects: international trade, development cooperation, and assistance for participation in the United Nations system (United Nations, 2018). The first point, international trade, includes preferential treatment for goods and services, and special measures related to the obligations of the WTO mechanism. In particular, with regard to goods, tax-free and quota-free market access and preferential rules of origin are available. For instance, the European Union (EU) has introduced the Everything but Arms initiative, under which about $99.8 \%$ of goods, excluding arms and ammunition, are duty-free. Japan also has a special preferential tariff system in which about $98 \%$ of goods are duty-free, excluding such items as fish, crustaceans, footwear, and sugar. The second point, regarding development cooperation, is related to the amount and modality of Official Development Assistance (ODA) in multilateral and bilateral cooperation. For instance, the Japan International Cooperation Agency (JICA), which is in charge of Japan's ODA, provides yen loans (e.g., general terms and conditions, fixed rate, standard) with an interest rate of $0.65 \%$ and a repayment period of 30 years (including a 10-year grace period) for "least developed countries or low income countries," while the interest rate is $1.15 \%$ and the repayment period is 30 years (including a 10-year grace period) for "lower middle income countries," which reduces the concessionality of the interest rate (Japan International Cooperation Agency (JICA), 2021). The third point, subsidies for participation in the United Nations system, includes discounts on annual expenditures to the United Nations and subsides for travel expenses related to participation in meetings.

Since the official establishment of the LDC status in 1971, the list has been revised. However only six countries, namely Botswana, Cape Verde, Maldives, Samoa, Equatorial Guinea, and Vanuatu, have graduated, while there are still 46 countries registered in the category as of December 2020. In the review meeting in 2018, Bangladesh, Myanmar, and Lao PDR were found to meet the graduation requirements. While Lao PDR met two of the three indicators (GNI per capita and HAI), as did previous graduating countries, Bangladesh and Myanmar were found to have met the requirements for all three indicators for the first time in the history (United Nations, 2020b). At the most recent review meeting in February 2021, CDP made graduation recommendations for three countries, Nepal in addition to Bangladesh and Lao PDR (United Nations, 2021). For Nepal, the first recommendation was made at the 2015 review meeting, but the decision was postponed in 2018, and the recommendation was made again in 2021 . For these three countries, the preparation period was extended to five years instead of three years in view of the impact of the Covid-19, and graduation was recommended to be in 2026. The decision on Myanmar, which was approved at the 2018 review meeting, was postponed due to the impact of the declaration of the state emergency issued by the national military. At the time of writing, the United Nations General Assembly and the United Nations Economic and Social Council have not yet announced a final decision.

\subsection{Japanese Policies on LDCs}

Developed countries have a scheme called the generalized system of preferences (GSP) that applies lower tariffs than the general tariff rates for products from developing countries, in order to facilitate developing countries to increase their revenues, industrialize, and develop their economies. This scheme was established by the United Nations Conference on Trade and Development (UNCTAD) in 1968, and has been implemented in Japan since 1971.

In addition, since 1980, Japan has given further preferential treatment called the special preferential tariff to LDCs, which allows duty-free and quota-free trade except for certain goods. Items subject to GSP and special preferential tariffs are specified in the Act on Temporary Measures concerning 
Customs as briefly described in the Table 1 (Tokyo Customs, 2020). In principle, LDCs are free of duty and quota on items other than those listed in Schedule 5 of the Act, which includes rice and rice-adjusted products, some fishery products, starch and starch-adjusted products, sugar, some leather products, etc. In general, about $98 \%$ of the items are duty-free. It is important to note that most of the goods listed in Chapter 61 and 62, which account for the majority of Japan's imports from Bangladesh, are listed in Schedule 4 of the Act. This means that as long as Bangladesh is an LDC, Japanese companies can import using duty-free and quota-free special preferential tariffs, while if Bangladesh graduates from the LDC status, Japanese companies cannot take advantage of even the GSP, and be applied Most Favored Nation (MFN) tariff rates. Therefore, majority of Japanese imports will be subject to tariffs of approximately $7.4 \%$ to $12.8 \%$, which is a significant increase.

Table-1.

Brief Illustration of GSP and Special preferential tariffs stipulated in the act on temporary measures concerning customs.

\begin{tabular}{l|l|l}
\hline & $\begin{array}{l}\text { Agricultural and Marin Products } \\
\text { Chapter 1 - 24 (Approx. 2,300 items) }\end{array}$ & $\begin{array}{l}\text { Mining and Manufacturing } \\
\text { Products } \\
\text { Chapter 25 - 97 (Approx. 7,000 } \\
\text { items) }\end{array}$ \\
\hline GSP & $\begin{array}{l}\text { In principle: } \\
\text { - Not applicable } \\
\text { Schedule 2 (Approx. 400 items): }\end{array}$ & $\begin{array}{l}\text { In principle: } \\
\text { - Duty-free, Quota-free } \\
\text { Schedule 3 (Approx. 1,100 items): } \\
\text { - As specified }\end{array}$ \\
& $\begin{array}{l}\text { Schedule 4 (Approx. 50 items): } \\
\text { - Not applicable } \\
\text { Schedule 5 (Approx. 1,000 items): } \\
\text { - Not applicable }\end{array}$ \\
\hline Special & $\begin{array}{l}\text { In principle: } \\
\text { Preferential }\end{array}$ & - Duty-free, Quota-free \\
Tariffs & - Duty-free, Quota-free & $\begin{array}{l}\text { Schede 5 (Approx. 50 items) } \\
\text { - Not applicable }\end{array}$ \\
\hline Schedule 5 (Approx. 160 items): & - Not applicable &
\end{tabular}

Source: Tokyo Customs, 2020.

\subsection{Bangladesh's Graduation from LDC Status}

In a preliminary analysis report submitted by the United Nations Department of Economic and Social Affairs, among the three special benefits for LDCs - international trade, development cooperation, and assistance for participation in the United Nations institutions - the impact of the loss of the international trade benefit is expected to be most significant, and described particularly in the textile industry in the EU, Canada, Japan and other markets (United Nations, 2020a).

When Bangladesh graduates from LDC status, many of the goods exported from Bangladesh to developed countries will be subject tariffs. As mentioned in the section 2.2. of this article, reasons that Bangladesh came to be a manufacturing hub of the textile industry are that it was not subject to the quota of the MFA and that it allowed the use of the special preferential tariffs for LDCs, and therefore it is questionable whether or not the supply chains remain as they are. In fact, past studies show that trade measures affect supply chains. For instance, although the situation may be different, Flaaen, Hortaçsu, and Tintelnot (2020) studied the impact of import restrictions on washing machines implemented by the United States, specifically on anti-dumping duties on South Korea in 2012 and anti-dumping duties on China in 2016. The study confirms that companies, in order to avoid paying import duties, shifted their production bases from Korea to China, then to Thailand and Vietnam, and finally to the United States. Hakobyan (2013) studied the impact of the temporary suspension of the GSP by the United States in 
2011 , and found that this led to an average decrease of $3 \%$ in exports from developing countries to the United States, and a $9 \%$ decrease in export of textiles and apparel in particular. The study also suggested that the decline in trade is replaced by domestic industries.

Awuah and Amal (2011) argue that institutional support from the government is essential on trade liberalization associated with globalization since it has an impact on the competitiveness of small and medium enterprises especially in LDCs. In fact, Bangladesh government itself has started examining the impact of graduation from LDC status. In the Perspective Plan 2021-2041 prepared by the General Economics Division, Ministry of Planning, Bangladesh in 2020 (General Economics Division Bangladesh Planning Commission Ministry of Planning Government of the People's Republic of Bangladesh, 2020) it is estimated that the country will graduate from LDC status in 2024 and that exports will decline by $11 \%$ or US $\$ 7$ billion per year in 2027 , when the country will no longer enjoy preferential treatment from the EU, Canada, Australia, Japan, India, and China. The report concludes, "the country has to prepare itself over the next few years to counter these losses". In addition, a paper of the researcher from the Policy Research Institute, Bangladesh (Razzaque \& Rahman, 2019) analyzes the impact of trade with the EU, including a US $\$ 1.6$ billion decline in exports and the possibility of China, Cambodia, India, Turkey, and Vietnam increasing their exports instead. Besides, in a paper written by Bangladesh government officials, it was pointed out that "a continuous effort should be given by the government by gaining experience from another developed country to reduce risk factors to ensure sustention of current progress" (Rahman, Sony, Rubel, Alam, \& Liza, 2020). It is evident that a sense of necessity is shared among the Bangladesh government. In December 2020, it was announced that Bangladesh's first bilateral Preferential Trade Agreement (PTA) had been signed with Bhutan (Dhaka Tribune, 2020). In March 2021, a bilateral joint communiqué was issued with Sri Lanka to work towards the early conclusion of a Free Trade Agreement (FTA) (ColomboPage, 2021) and in the same month, a bilateral joint statement was issued with India to expedite the joint study of a Comprehensive Economic Partnership Agreement (CEPA) (Ministry of External Affairs Government of India, 2021) indicating that the Bangladesh government is making preparations at a rapid pace.

For countries graduating from LDC status, developed countries may continue to provide preferential treatment for a certain period of time after graduation in order to assist with a "smooth transition". For example, the EU and Turkey have a scheme of providing a three-year transition period after graduation, and such countries as the US, Canada, Australia, India, and South Korea have in the past continued to provide preferential treatment even though they do not have an established scheme. As Rahman and Bhattacharya (2020) and others point out, there are growing demands for a review of the benefits, including an extension of the transition period in order to respond to the Covid-19 and protectionism or to be a good model for the future graduating countries. On the contrary, however, Japan does not have a precedent of continuing the measures after LDC graduation (United Nations, 2018).

In the Act on Temporary Measures concerning Customs, it is only stipulated that special preferential tariff be withdrawn within one year of the resolution to be removed from the LDC list, and there is no specific provision on the transition period. Considering that there is a large number of Japanese people and workers in the countries graduating from the LDC list in the near future, it is critical to analyze the impact the LDC graduation has on Japanese companies.

\section{Methodology}

In order to investigate the impact on companies dealing with imports and exports, an online questionnaire was sent to Japanese companies in Bangladesh from JETRO Dhaka Office and Dhaka Japan Chamber of Commerce and Industry from February 24 to March 15, 2021. In total, we received responses from 47 companies (response rate of around 44\%). The next section describes the findings from the questionnaire and what can be discussed from the results. 


\section{Findings and Discussion}

\subsection{Questionnaire Survey}

Among those companies that responded, 23 companies were utilizing the special preferential tariffs and the remaining 24 companies were not utilizing them. Besides, out of the companies that use special preferential tariffs, $80 \%$ of the products were related to the chapter 61 , chapter 62 , and chapter 63 (other articles of apparel and clothing accessories). As for the export destinations of these items that are produced in Bangladesh, $56 \%$ are Japan, $21 \%$ are EU, and $10 \%$ are the United States.

In response to the question "Has your company started to consider how to deal with the graduation from Least Developed Countries (LDCs) status?", Table 2 shows the classification of companies that answered "Not yet", "Began to gather information", and "Began to take action" into two groups: those that are utilizing the special preferential tariffs and those that are not. With the null hypothesis that the use of special preferential tariffs and the initiation of information gathering are independent of each other, the chi-square test for independence yields a chi-square statistic of 11.902 . Since the upper $5 \%$ point of the chi-square distribution with 1 degree of freedom is 3.841, the null hypothesis is rejected at the $5 \%$ level of significance, and it can be concluded that the use of special preferential tariffs and the initiation of information gathering are not independent, but they may be related.

Therefore, it can be said that the companies that are utilizing the special preferential tariffs, compared to those companies that are not, are more sensitive and have started gathering information on LDC graduation of Bangladesh. This difference is natural since the graduation from LDC status is followed by the abolishment of special preferential tariffs. On the other hand, it can also be discussed that companies that are not utilizing the special preferential tariffs are encouraged to start gathering information because their surrounding business environment will inevitably change.

Table-2.

Cross tabulation table between the use of special preferential tariffs and the initiation of information gathering.

\begin{tabular}{l|c|c|c}
\hline & $\begin{array}{c}\text { Began to gather information/ } \\
\text { Began to take action }\end{array}$ & $\begin{array}{c}\text { Not yet } \\
\text { considering }\end{array}$ & Total \\
\hline $\begin{array}{l}\text { Utilizing Special Preferential } \\
\text { Tariffs }\end{array}$ & 14 companies & 9 companies & 23 companies \\
\hline $\begin{array}{l}\text { Not Utilizing Special } \\
\text { Preferential Tariffs }\end{array}$ & 3 companies & 21 companies & 24 companies \\
\hline $\begin{array}{l}\text { Total } \\
\text { Source: The questionnaire survey conducted by JETRO Dhaka Office and Dhaka Japan Chamber of Commerce and Industry. }\end{array}$
\end{tabular}

Second, Figure 2 shows the responses to the question "Do you foresee any changes in your company's supply chains?" for the 47 Japanese companies operating in Bangladesh, and about 30\% of the companies answered that they might move their production bases or do something similar. Moreover, in response to the question about where they might move production bases, those companies that may move their productions bases answered as shown in Figure 3. ASEAN countries, which are closer to Japan than Bangladesh, were the main destinations for the transfer of their production bases. One of the reasons raised for transferring production bases was that various costs - for example, that Bangladesh is remote from Japan and difficult to manage production; that there are hardships due to cultural and religious differences; and that there are frequent delays in $\mathrm{L} / \mathrm{C}$ decisions and untransparent procedures - would prevail over the advantages such as the scheme of special preferential tariffs, and thus it would become less meaningful to locate a production base in the country. Another reason for relocating production bases was the growing comparative advantages of Southeast Asian countries, where the Regional Comprehensive Economic Partnership (RCEP) agreement and many FTAs are being arranged. On the other hand, those that are not planning to relocate their production bases argued that doing businesses for domestic customers would not be affected by the graduation, or that they can keep taking advantage of relatively reasonable and abundant work force. 
The implication from these findings is that Bangladesh needs to consider maintaining low tariffs in order to maintain foreign direct investment, and also to urgently eliminate the various costs mentioned above. At the very least, Bangladesh needs to develop a business environment that is comparable to that of Southeast Asian countries. On the other hand, one implication for Japanese companies is that if they want to continue business in Bangladesh, they should consider shifting their focus to domestic demand, since the population is large and the middle class has high potential.

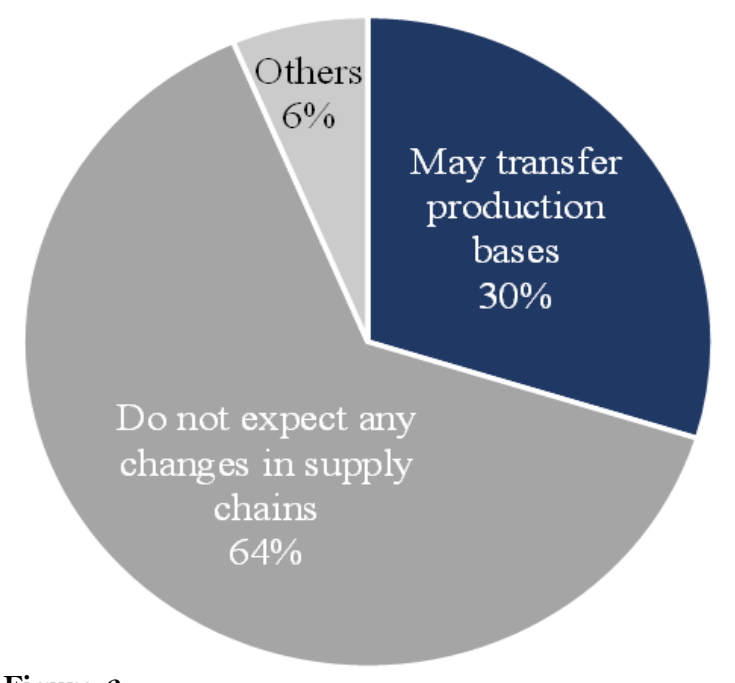

Figure-2.

Answers about Changes in Supply Chains.

Source: The questionnaire survey conducted by JETRO Dhaka

Office and Dhaka Japan Chamber of Commerce and Industry

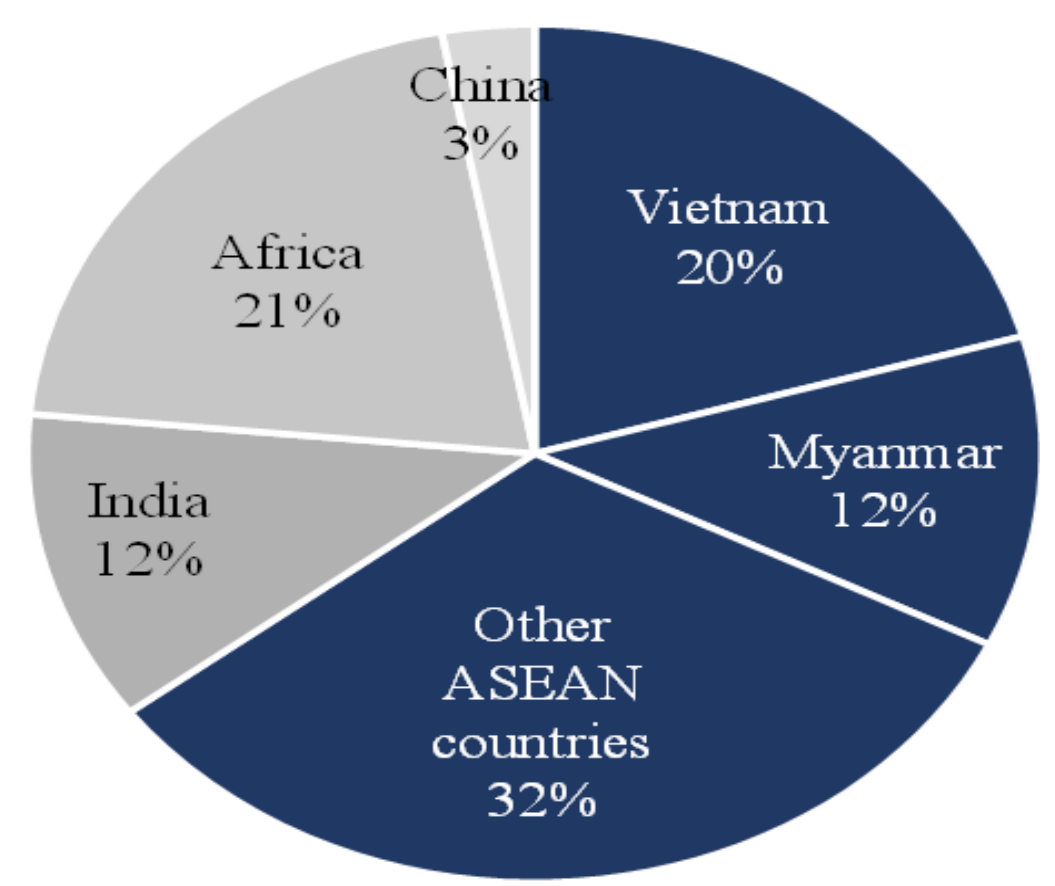

Figure-3.

Answers about Possible Destinations to Relocate Production Base.

Source: The questionnaire survey conducted by JETRO Dhaka Office

and Dhaka Japan Chamber of Commerce and Industry

Journal of Contemporary Research in Social Sciences
ISSN : 2641-024.9
Vol. 3, No. 2, pp. $28-39,2021$
DOI: $10.33094 / 26410249.2021 .32 .28 .39$
C) 2021 by the authors; licensee Learning Gate


Third, Table 3 shows a cross tabulation table of the companies that responded they may transfer their production bases and those that responded that they do not expect any change in their supply chains, based on whether or not they are currently utilizing special preferential tariffs. The null hypothesis is that the use of special preferential tariffs and the attitude towards the transfer of production bases are independent of each other, and a chi-square test for independence is conducted. Because the sample sizes of some items are small, the chi-square statistic with Yate's correction was employed and calculated to be 19.521. Since the upper 5\% point of the chi-square distribution with 1 degree of freedom is 3.841 , the null hypothesis is rejected at the $5 \%$ level of significance, and we concluded that the use of special preferential tariffs and the idea of transferring production bases are not independent, but they may be related.

Therefore, it can be seen that the more a company utilizes special preferential tariffs, the more likely it is to consider transferring the production bases. Considering the discussions above, this suggests that companies that utilize the special preferential tariffs are making vertical foreign direct investments to save on production costs, rather than horizontal foreign direct investment, which aims at saving on transportation costs by bringing the production base close to the market (Tanaka, 2011).

As for Bangladesh, it will be necessary to urgently consider implementing measures to prevent companies from leaving their country upon graduation from LDC status. On the other hand, as for Japanese companies, they need to be reminded that not only Bangladesh but also Lao PDR, Nepal, and Myanmar are also expected to graduate from LDC status at almost the same time. Japanese companies should consider the whole picture aside from the special preferential tariffs to strategize about the construction of optimal supply chains.

It is also noteworthy that many Japanese companies operating in Bangladesh have expressed a desire for Bangladesh government to consider an FTA in this questionnaire survey. It is not an easy task for governments since the FTA needs to address not just the domestic industries but also some political and diplomatic points of view, but it may be worth considering in light of the various effects we have seen so far.

Table-3.

Cross tabulation table between the use of special preferential tariffs and the observations on transfer of production bases.

\begin{tabular}{l|c|c|c}
\hline & $\begin{array}{c}\text { May transfer } \\
\text { production bases }\end{array}$ & $\begin{array}{c}\text { Do not expect any } \\
\text { changes in supply chains }\end{array}$ & Total \\
\hline $\begin{array}{l}\text { Utilizing Special } \\
\text { Preferential Tariffs }\end{array}$ & 14 companies & 7 companies & 21 companies \\
\hline $\begin{array}{l}\text { Not Utilizing Special } \\
\text { Preferential Tariffs }\end{array}$ & O companies & 23 companies & 23 companies \\
\hline Total & 14 companies & 30 companies & 44 companies \\
\hline
\end{tabular}

\subsection{Global Supply Chains and Way Forward}

Finally, we would like to add that it is essential for Bangladesh to be kept integrated into the global supply chains in order for it to upgrade its industrial structure. As lessons learned from the Covid-19 pandemic, strong and resilient supply chains ensure the stable economies. In this sense, Bangladesh's regional connectivity would contribute not only to Bangladesh's national interest but also to the interests of Japanese companies operating in the country and Japan itself. Here we would like to briefly discuss two measures for regional connectivity.

First point is the upgradation of globalization. It has become clear that international cooperation through multi-national frameworks is effective in taking coordinated actions against global risks such as Covid-19 pandemic. Japan has such frameworks with ASEAN countries as far as Myanmar, which is located east of Bangladesh, and has another relationship, such as Japan-US-Australia Strategic Dialogue, with India, which is located west of Bangladesh. Nevertheless, Japan and Bangladesh does not share a 
regional framework, except for the global framework of the WTO. The establishment of a regional framework with Bangladesh, such as a future Economic Partnership Agreement (EPA) would be important for economic cooperation.

Second point is the establishment of resilient supply chains. For Japanese companies operating in the region, it is extremely important to build supply chains that can respond to unexpected emergencies flexibly. According to the World Bank Group Doing Business's Trading across Borders Index (World Bank, 2020) Bangladesh ranks 176th in the world for ease of doing business in cross-border trade. The time and cost of importing is estimated to be 1.5 to 3 times higher than the average of South Asian countries. In fact, Japanese companies have raised concerns on the lengthy process from cargo arrival to the completion of import customs clearance as a risk for investment and business, and these improvements are essential for building resilient supply chains. Although Bangladesh seems to focus on sea and air cargo, the land border between India and Bangladesh also has much room for improvements.

\section{Conclusion}

This article explained that business environment will change in Bangladesh after graduation from LDC status. In order to minimize this impact, Bangladesh government will need to implement a variety of initiative at a rapid pace, such as improving the business environment, concluding EPAs and FTAs, diversifying trade, and strengthening regional connectivity. In order to support these efforts, Japanese government, together with the Japan-Bangladesh Committee for Commercial and Economic Cooperation, is making efforts to cooperate through the Japan-Bangladesh Public-Private Joint Economic Dialogue, which are held regularly between the two countries.

Coincidentally, at the time of writing, the year 2021 marks the 50th anniversary of Bangladesh's independence, and the following year, 2022, would mark the 50th anniversary of the establishment of bilateral diplomatic relation, and the Bangladesh government is building momentum for the Golden Jubilee in a numerous way. As previously discussed, the bilateral relationship between the two countries is better than ever. It is encouraged to bring all the wisdoms to enrich and deepen the friendship further.

\section{References}

Awuah, G., \& Amal, M. (2011). Impact of globalization: The ability of less developed countries'(LDCs') firms to cope with opportunities and challenges. European Business Revier, 23(1), 120-132. Available at: https://doi.org/10.1108/09555341111098026.

Bangladesh Garment Manufacturers and Exporters Association (BGMEA). (2020). Export performance - comparative statement on export of RMG \& total export of Bangladesh. Retrieved from: https://www.bgmea.com.bd/page/Export Performance.

ColomboPage. (2021). Joint communique on Sri Lanka Prime Minister's state visit to Bangladesh. Retrieved from http://www.colombopage.com/archive_21A/Mar20_1616251532CH.php.

Dhaka Tribune. (2020). Bangladesh signs preferential trade agreement with Bhutan. Retrieved from https://www.dhakatribune.com/bangladesh/2020/12/06/bangladesh-signs-preferential-trade-agreement-withbhutan.

Export Promotion Bureau Government of the People's Republic of Bangladesh. (2020). Product wise export (Goods) for the month of July-June 2019-20. Retrieved from http://epb.gov.bd/site/view/epb_export_data/.

Flaaen, A., Hortaçsu, A., \& Tintelnot, F. (2020). The production relocation and price effects of US trade policy: The case of washing machines. American Economic Review, 110(7), 2103-2127. Available at: https://doi.org/10.1257/aer.20190611.

Fukasawa, M. (2014). A study on the structure of the developing country's economy: A case study of the Bangladesh's economy. Retrieved from Meiji University Academic Repository http://hdl.handle.net/10291/17456.

General Economics Division Bangladesh Planning Commission Ministry of Planning Government of the People's Republic of Bangladesh. (2020). Making vision 2041 a reality perspective plan of Bangladesh 2021-2041. Retrieved from http://oldweb.lged.gov.bd/UploadedDocument/UnitPublication/1/1049/vision\%202021-2041.pdf.

Gereffi, G. (1999). International trade and industrial upgrading in the apparel commodity chain. Journal of International Economics, 48, 37-70. Available at: https://doi.org/10.1016/So022-1996(98)00075-0.

Hakobyan, S. (2013). GSP expiration and declining exports from developing countries. Canadian Journal of Economics, 53(3), 1132-1161. Available at: https://doi.org/10.1111/caje.12454.

International Finance Corporation (IFC). (2020). Bangladesh's journey to middle-income status: The role of the private sector. Retrieved

from 
https://www.ifc.org/wps/wcm/connect/region_ext_content/ifc_external_corporate_site/south+asia/resources/ba ngladesh+journey+to+middle+income + status + the + role + of + the+private + sector.

Japan International Cooperation Agency (JICA). (2021). Terms and conditions of Japanese ODA loans. Retrieved from https://www.jica.go.jp/english/our_work/types_of_assistance/oda_loans/standard/index.html. [Accessed April 1, $2021]$

Kobayashi, K. (2013). The world's leading sewing factory Bangladesh - exploring its capabilities as a labor-intensive production base. Mizuho Research Institute Research Report.

Komori, M. (2017). A study of Japanese firms' clustering and innovation creation in Bangladesh. Asia University Management Revierw, 52(2), 19-33.

Ministry of Economy Trade and Industry Government of Japan. (2020). White paper on international economy and trade 2020. Retrieved from https://www.meti.go.jp/english/report/data/wp2020/wp2020.html.

Ministry of External Affairs Government of India. (2021). Joint Statement issued on the occasion of the visit of Prime Minister of India to Bangladesh. Retrieved from https://www.mea.gov.in/bilateraldocuments.htm? dtl/33746/Joint+Statement+issued +on+the+occasion +of +the+visit + of $+\overline{\text { Prime }+ \text { Minister }+ \text { of }+ \text { India }}$ + to+Bangladesh.

Murayama, M., \& Yamagata, T. (2014). Bangladesh: The unknown industrialized country. Chiba, Japan: IDE-JETRO.

Nagata, H. (2012). Bangladesh as the Japanese ready-made garment corporation's secondary transfer: The gender analysis of international capital transfers. Journal of the Japanese Association for South Asian Studies, 2012(24), 103-131. Available at: https://doi.org/10.11384/jjasas.2012.103.

Rahman, M. (2011). Trade benefits for least developed countries: The Bangladesh case market access initiatives, limitations and policy recommendations. CDP Background Papers No. 018, United Nations, Department of Economics and Social Affairs.

Rahman, M., \& Bhattacharya, D. (2020). Sustainable graduation: International support measures for graduating LDCs. International Trade Working Paper No. 2020/10. Commonwealth Secretariat, London.

Rahman, Z., Sony, M., Rubel, S. H., Alam, M., \& Liza, R. A. (2020). Steps toward smooth graduation of Bangladesh from least development. Journal of Contemporary Research in Social Sciences, 2(3), 57-67. Available at: https://doi.org/10.33094/26410249.2020.23.57.67.

Razzaque, M. A., \& Rahman, J. (2019). Bangladesh's apparel exports to the EU: Adapting to competitiveness challenges following graduation from least developed country status. International Trade Working Paper No. 2019/02, Commonwealth Secretariat, London.

Shintaku, J., Tomino, T., \& Itohisa, M. (2013). Possibility of manufacturing with the apparel industry in Bangladesh. Akamon Management Review, 12(11), 777-794.

Tanaka, A. (2011). Why do companies move their production bases overseas? Types of foreign direct investment: RIETI International Trade and Trade Policy Research Memo. Retrieved from: https://www.rieti.go.jp/users/tanakaayumu/serial/o06.html.

Tokyo Customs. (2020). General preferential tariff manual. Retrieved from https://www.customs.go.jp/roo/origin/ippan.pdf.

United Nations. (2018). Handbook on the least developed country category: Inclusion, graduation and special support measures third edition. United Nations publication. https://www.un.org/development/desa/dpad/publication/handbook-on-the-least-developed-country-categoryinclusion-graduation-and-special-support-measures-third-edition/.

United Nations. (2020a). Ex ante assessment of the impacts of the graduation of Bangladesh from the category of least developed countries (LDC) revised. Retrieved from https://www.un.org/development/desa/dpad/wpcontent/uploads/sites/45/IA-Bangladesh-2019.pdf.

United Nations. (2020b). The least developed countries report 2020 productive capacities for the new decade. New York: United Nations Publication.

United Nations. (2021). Committee for development policy 2021 plenary and triennial review. Retrieved from https://www.un.org/ldcportal/committee-for-development-policy-2021-plenary-and-triennial-review/.

World Bank. (2020). Doing business measuring business regulation. Retrieved from https://www.doingbusiness.org/en/data/exploretopics/trading-across-borders.

World Bank. (2021). World bank open data. Retrieved from https://data.worldbank.org/.

Journal of Contemporary Research in Social Sciences
ISSN : 2641-0249
Vol. 3, No. 2, pp. $28-39,2021$
DOI: $10.33094 / 26410249.2021 .32 .28 .39$
C) 2021 by the authors; licensee Learning Gate

